\title{
FISHERMEN'S PERCEPTION IN SUPPORTING THE USAGE OF SUSTAINABLE FISHING EQUIPMENT IN BANDA SAKTI SUBDISTRICT OF LHOKSEUMAWE CITY
}

\author{
Handayani Aqlia, Indra*, Sarong Ali \\ Graduate Program, University of Syiah Kuala, Indonesia \\ *E-mail: rizaramadhanbaron@gmail.com
}

\begin{abstract}
Indonesian marine waters store abundant potential of non-biological resources. The population of Lhoksumawe consists of fishermen which have 1,827 people, all of whom are engaged in fisheries whose territory and catch are from the Malacca Strait waters. The purpose of this study was to examine the fishermen's perceptions in Banda Sakti Subdistrict, Lhokseumawe City on the utilization of sustainable fishing equipment and analyze the relationship of socio-economic characteristics with fishermen's perceptions of the utilization of sustainable fishing equipment. The method used in this study is a quantitative method that is using the class interval formula to see the level of perception and Rank Spearman correlation analysis to see the relationship that occurs. The results showed the level of perceptions of fishermen on the utilization of sustainable or environmentally friendly fishing equipment is high, with perceptual score values within the range $>224-288$. Meanwhile, the socio-economic characteristics that have a relationship with the perceptions of fishermen are in the variables: income, number of dependents and socialization; namely the perception of the level of selectivity and the level of security of fishing equipment. The level of correlation in the income variable and the number of dependents on selectivity fishing equipment has a low level of correlation within the range of $0.20-0.399$. Only on the socialization variable on the perception of fishing equipments' security is at a moderate level of correlation; with the correlation coefficient value of 0.571 . For other variables, the level of correlation coefficient is very low with a significance value of $>0.05$.
\end{abstract}

\section{KEY WORDS}

Socio-economic characteristics, perception, sustainable fishing equipment, Banda Sakti.

The potential of Indonesian marine fisheries is appreciable enough to contribute significantly to fisheries development. The development of fisheries as part of national economic development has objectives: to improve the living standard and the welfare of fishermen and fish farmers. To create such conditions, it is necessary to provide various facilities in obtaining various facilities that can support the success of the fishery business, including the ease of obtaining production facilities or supplies to go to sea and guarantee of marketing. Therefore, there will be efficient proccess from the production to marketing.

Indonesian marine waters store abundant potential of non-biological resources. There are still many Indonesian waters that have economic potential but have not been adequately managed. In addition, the potential for renewable energy from the sea, such as deep sea water, is still become a challenge to be developed and be utilized in the future. The maritime industry, biotechnology, marine services, salt production and its derivatives, marine biopharmacology, seawater utilization other than energy, submarine pipelines and cable installations, and / or the removal of sinking objects and cargo vessels; are sub-sectors of the sea potential that have not been optimally managed.

The size of the potential and benefits of Indonesia's seas should have become a new driver of Indonesia's economy in the future. Fishing and fish farming activities have also continued to increase since the 1980s, such as the development of marine aquaculture for various types of fish, such as groupers, snapper, and baronang; pond cultivation such as shrimp and milkfish; and freshwater cultivation such as goldfish, carp, pangasius and others. (Regulation of the Minister of Maritime Affairs and Fisheries No. 25/PERMEN-KP/2015). 
Many regulations and supervisions have not been effective in achieving the objectives of sustainable fisheries management. There are still many fishermen who are only concerned with the aspect of catches when they go fishing become an unsynchronous government program on sustainable capture fisheries. For that reason, there needs to be an understanding given about natural sustainability factors for fishermen to synchronize the program.

The Lhokseumawe's population consists of fishermen with a total of 1,827 people, all of whom are engaged in capture fisheries whose territory and catch are from the Malacca Strait waters. Some types of fish produced include tuna, snapper, mackerel, anchovies and several other species. The fishing equipment used by fishermen in Banda Sakti Subdistrict, is quite varied; including fishing nets, fishing rods and trawlers of various sizes. In bringing together fishermen's perceptions of the utilizatiom of sustainable fishing equipment, it is necessary to conduct a study to measure the level of perception of fishermen on environmentally friendly fishing equipment. Therefore, it is expected that the diversity of fish's biological resources will be maintained.

The perception of fishermen in Lhokseumawe on the utilization of fishing ewquipment is inseparable from the social and economic factors of the community. Social capital is a resource that involves the expectation of achieving goals involving a wider network in which there are relationships that are governed by the level of trust and shared values. Social capital is inherent in the structure of relations between and among actors (Coleman, 2009). Social capital is a series of resources that make up networks; those resources are economic capital, social capital, cultural capital, values, norms and beliefs.

Lhokseumawe has its potential to be developed especially in coastal and marine areas with its management which refers to the condition of human resources and local wisdom in managing local ecosystems. Some important aspects to consider in regional development and management activities are human resources; inseparable from the influence of characteristics attached to them.

This study aimed to determine and analyze the level of perception of fishermen in Banda Sakti Subdistrict, Lhokseumawe City on the utilization of sustainable fishing equipment, so it is necessary to find out what can affect the perception of fishermen in Lhokseumawe; where this is one of the first steps that can be taken to unite the perception of the utlization of sustainable fishing equipment. Furthermore, it will be synchronized between socio-economic characteristics with the perception of fishermen in Banda Sakti Subdistrict, Lhokseumawe City in supporting the utilization of sustainable fishing equipment.

\section{METHODS OF RESEARCH}

This study examines the perceptions of fishermen in Banda Sakti Subdistrict, Lhokseumawe City on the utilization of sustainable fishing equipment. The scope of this study is the socio-economic characteristics of fishermen including age, education, experience, income, number of dependents and socialization of fisheries that have been followed and the perception of fishermen on the utilization of sustainable fishing equipment.

The type of data used in this study consists of primary data and secondary data. The source of primary data is obtained through in-depth interviews with respondents assisted by questionnaires that have been provided. The questionnaire that was distributed was about the characteristics of the respondents and other questions related to perception. Secondary data is obtained from various sources regarding informations related to the topic discussed. Secondary data sources are obtained from books, research journals, articles, magazines and the internet.

The population of the study was fishermen in Banda Sakti Subdistrict, Lhokseumawe City, as many as 904 people. The sample was set at 96 people from the target population (Table 2). The number of the sample taken is in accordance with Gay's statement (1976, in Mujiburrahmad, 2013) which states that the minimum acceptable size for the correlation study is 30 subjects. Sample selection is done through simple random sampling with the provision of sampling $10 \%$ of the population per village. 
Fishermen's perception of sustainable fishing equipment in Banda Sakti Subdistrict, Lhokseumawe City was analyzed using quantitative descriptive method. Afterwards, the data obtained was tabulated and analyzed by scoring techniques. The criteria for scoring are score 3 for answers that show high perceptions, score 2 for answers that indicate moderate perceptions and score 1 for answers that show low perceptions. The scale used in determining this score uses a modified Likert scale without neutral choices to avoid hesitant answers. Modification of the Likert scale according to Hadi (1991); can be done based on two reasons, namely the middle answer gives a double meaning, and also raises doubts of the respondent in answering then makes them choosing the middle (neutral) answer.

Based on perceptual scores on each of the following indicators (1) Respondent's perception if a fishing equipment has high selectivity; (2) Respondent's perception if a fishing equipment does not damage habitat and other organisms; (3) Respondent's perception if a fishing equioment produces good quality fish; (4) Respondent's perception if a fishing equipment does not harm the fishermen who operate; (5) Respondent's perception if a fishing equipment catches fish that is safe for consumption; (6) Respondent's perception if a fishing equipment has a small by-catch; (7) Respondent's perception if the operation of a fishing equipment has a low impact on biodiversity; (8) The respondent's perception if a fishing gear does not catch protected fish; and (9) Respondent's perception if an equipment is socially accepted by the community.

\section{RESULTS AND DISCUSSION}

Socio-economic characteristics are the basic things for everyone to communicate within a community. This is the resource of each person used to carry out a community process. Fishermen's socio-economic characteristics in this study including age, education level, experience of being a fisherman, total income, number of dependents and number of participation in socialization activities.

Age is the the data about the age of respondents at the time of the study. Age categories are classified according to age categories made by the Ministry of Health of the Republic of Indonesia in 2009, then classified into three categories: adolescents, adults and elder. The average age of fishermen in the research location is elder with the experience of being a qualified fisherman. The results of the interview also found that the skills of being a fisherman were mostly hereditary knowledge from their parents and the fishing equipment used was also relatively simple.

The education level of fishermen in the study locations shows that the average fisherman in Lhokseumawe has completed 12 years of education; exceeding the government's target of 9 years of compulsory education. The level of education also influences one's mindset and adaptation to accept new things. The higher the education level of fishermen, it is expected that it will also be easier to receive innovations or programs implemented either from the government or other institutions in the fisheries sector.

The experience of being a fisherman is a process of forming or skill a fisherman in fishing. The average experience of fishermen in research locations has undergone the profession since the age of adolescence, which is between the ages of 12-25 years. This means that the fishermen in the research location have had considerable experience in terms of fishing which is becomes a permanent livelihood for him.

Earning is a representation of the economic situation of fishermen in the research location. Earning in this study are classified based on the amount of Upah Minimal Provinsi (Aceh Regional Regional Wages; UMP) in 2018, which is Rp.2,700,000. The results of the study showed that fishermen's income is low, that is, the average is below the UMP Aceh in 2018. This means that it is a need for community empowerment especially for fishing fishermen to increase their earning. Fishermen's earning is also inseparable from the number of family dependents owned by the fishermen. The more dependents the fishermen's family has, the greater the income that the fishermen must have to fulfill their family's needs.

Socialization is activities that must be done to carry out a program that will be implemented. The socialization of fisheries can be a reference for the government to 
implement all fisheries regulations in the field of capture fisheries related to the profession of fishermen themselves. But the results of the study showed that only 4 subjects had attended socialization about fisheries, the rest said that they had never attended training or socialization or all matters related to their work as fishermen. The results of interviews with several fishermen who had participated in the socialization stated that there hasn't been any socialization since the last post-tsunami socialization carried out by the Agency of Aceh Reconstruction and Rehabilitation (BRR).

Fishermen's Perception of the Utilization of Sustainable Fishing Equipment. Sustainable fishing equipment is environmentally friendly fishing equipment. Data on fishermen's perception of the utilization of sustainable fishing equipment was collected by directly interviewing respondents; fishermen in Banda Sakti Subdistrict, Lhokseumawe City on 9 criteria for environmentally friendly fishing equipment according to Conduct for Responsible Fisheries (CCRF). Furthermore, the scores of the 9 criteria are adjusted to the level of perceptions of fishermen on the utilization of sustainable fishing equipment. The level of perception used is obtained from the class interval formula with a score of 96-160 classified as low perceptions, scores of $>160-224$ classified as moderate perceptions and scoresof $>224-288$ classifed as high perceptions. From the results of the analysis it was found that the perception of fishermen on the use of sustainable fishing equipment in Banda Sakti Subdistrict in Lhokseumawe City was at a high level of perception with a score of 230. However, when viewed from each criterion assessed, 5 criteria had moderate perceptions and 4 had high perceptions. This is in accordance with the results of Bachtiar's (2003) study which shows that the perception of fishermen in utilizing marine resources on Kodingareng Island as a whole is in two categories: moderate and good. While poor perceptions are not found in this study. But the percentages of fishermen's perceptions that are good for those who do non-destructive (sustainable / environmentally friendly) fishing are higher than those who make destructive fishing (using bombs and anesthesia). In other words, fishermen who carry out destructive captivity tend to have a worse perception of coral reefs or the sustainability of other natural resources found at the study site.

Relationship Between Socio-Economic Characteristics and Fishermen's Perception in the Utilization of Sustainable Fishing Equipments. This relationship of fishermen's socioeconomic characteristics to the perceptions of fishermen in the utilization of sustainable fishing equipment was examined between variables of age, education level, fishing experience, number of dependents, income and socialization of fisheries that had been participated; to fishermen's perceptions based on 9 criteria according to CCRF which included (1) Respondent's perception if a fishing equipment has high selectivity; (2) Respondent's perception if a fishing equipment does not damage habitat and other organisms; (3) Respondent's perception if a fishing equioment produces good quality fish; (4) Respondent's perception if a fishing equipment does not harm the fishermen who operate; (5) Respondent's perception if a fishing equipment catches fish that is safe for consumption; (6) Respondent's perception if a fishing equipment has a small by-catch; (7) Respondent's perception if the operation of a fishing equipment has a low impact on biodiversity; (8) The respondent's perception if a fishing gear does not catch protected fish; and (9) Respondent's perception if an equipment is socially accepted by the community.

The relationship of socio-economic characteristics to fishermen's perceptions if fishing equipment has high selectivity indicates that the socio-economic characteristic variables that are significantly related to these perceptions are only in the variable number of dependents where the significance value is less than 0.05; this is due to the fact that a family head who has more dependents must generate more income to meet the needs of their family, from field observations, generally, fishermen are more interested in using fishing equipment which they think has more continuous results and a uniform / selective size (unvarying size); therefore the results obtained tend to be more correspond with the target of the catch. Besides, the reasons of not to bound and the results of sales that can be sold on their own; are also become the main reasons for using fishing equipment. This is in accordance with the statement of Symes (2012) which states that longline fishing equipment has lower catch ability than trawler fishing equipment which produces more quantity and solid catches. 
However, the longline provides a higher long-term catch than trawl which has a very high level of exploitation.

Meanwhile, other variables have a non-significant relationship. The resulting correlation that also shows the direction of a negative relationship is on the variables of age, education level, experience and the number of dependents on perceptions regarding selectivity of fishing equipmen; this means that the higher the value of these variables, it may produce lower perceptions of the use of sustainable fishing equipment. The results of field observations found that this happened because in general, fishermen still took all the catches that could be sold even though the size and type were different especially when the catch was reduced. As the results of the Benardo (2017) which show that the perceptions of fishermen in the research location assess as "not good" if the fishing equipment has a high selectivity, because in research locations where prohibited fishing equipment such as tiger trawlers can damaging waters, habitats and fish resources that are not become the target of the catch.

The relationship of socio-economic characteristics to fishermen's perceptions if a fishing equipment does not damage habitat and other organisms shows a very low level of correlation and insignificant relationship, meaning that there is no relationship between fishermen's socio-economic characteristics and fishermen's perception of the utilization of fishing equipment that does not damage habitat and other organisms. This is in accordance with the results field observations which says that all fishermen agreed that sustainable fishing equipment should not a destructive fishing equipment such as tiger trawlers, fish bombs and fish poisons. However, based on the information of fishermen, there are still boats that use fishing equipment that damages the environment. So that there are still many fishermen who are disturbed by the existence of those fishing equipment, especially small fishermen who use longline nets and fishing lines which are made restless by those fishing vessels. Based on the information of several fishermen, there were not many fishermen that use such damaging environment equipment, but it was quite disturbing to other activities. For this reason, a government policy is needed to regulate these activities so that the presence of fish and the environment is maintained. As Doulman (2004) stated in his research, that in minimizing the adverse effects of overfishing and damaging the environment activities, the steps taken must lead to an approach that involves the first person, and focuses attention on the activities of resource users rather than the resources itself, because the first thing to manage is the activity is not the fish.

Fishing equipment is supposed to produce good quality fish where the catch has a fresh condition (neither damaged nor decayed) since poor conditions can reduce selling value or even it can be harmful to consumers. Based on the results of the analysis, it was found that the relationship between socio-economic characteristics of fishermen's perception if a fishing gear produces good quality fish, produces a correlation relationship with very low levels and does not have a significant relationship to fishermen's perception of fishing equipment if producing good quality fish. This is because all respondents agree with the statement that says environmentally friendly fishing equipment is good quality fishing equipment that has good quality catches. The overall field observations showed that the catches of fishermen in Lhokseumawe are in good quality and fresh catch, because fishermen generally catch fish in a day away, not taking days at sea. In addition, based on direct interviews with the Sea Commander, Fisheries Extension and Syahbandar in Lhokseumawe, so far there have been no reports or complaints from local people about the poor catch of the fishermen.

Fishing equipment that does not harm fishermen is also sustainable or environmentally friendly fishing equipment. The relationship between socio-economic characteristics to the perception of fishermen if a fishing equipment does not harm the fishermen who operate it, is found that the socialization variable has a higher relationship than the other variables. The results of the analysis indicate that the resulting correlation coefficient is at a moderate level of 0.571 with a significance smaller than 0.05 . This shows that socialization has a significant relationship to fishermen's perception if fishing equipment used does not harm fishermen; this means that socialization can be a way to educate fishermen about safe fishing 
equipment and not harm fishermen so that it is expected to reduce the utilization of fishing equipment that can harm fishermen.

As safe fishing equipment for fishermen, as well as good fishing equipment must also produce fish that are safe for consumption. Inappropriate use of fishing equipment not only damages sustainability but also disrupts consumers' health. The relationship of socioeconomic characteristics to the perceptions of fishermen if a fishing equipment is safe for consumption has a very low level of correlation where age, education, experience, income, number of dependents and socialization do not have a significant relationship; so that it is considered unable to change the perception of fishermen to use fishing equipment that produces safe fish for consumption.

Fishing equipment that has little by-products is environmentally friendly fishing equipment and is considered to be able to maintain the fisheries ecosystem and its own resources. The fewer by-products produced by a fishing equipment, the fewer catches of small fish and other marine biota that do not need to be caught participating in the fishing equipment used. The results of the analysis are in accordance with the results of Firdaus's research (2010) which stated that the use of fishing equipment such as trawl has a by-catch and discarded catch. The field observations also found that by-products that did not reach adult size or had smaller sizes would also be taken and sold as fish feed or consumed if the main catches were produced only in small amount.

The fishing equipment used by fishermen should not catch protected fish. Moreover, the commodity is a group of fish that is almost extinct. This is to preserve natural resources in the sea in order to continue to breed so that future generations can enjoy the beauty of the sea with a variety of biological resources in it. The relationship between socio-economic characteristics to the perception of fishermen if fishing equipment does not catch protected fish is at very low level of correlation with a significance value greater than 0.05 ; means that all variables analyzed for socio-economic characteristics have no relationship to perception fishermen if a fishing equipment does not catch protected fish. From the results of interviews, it was found that there were still fishermen who claimed to have been caught protected fish, but generally, they let go back because according to them the fish did not have economic value, and if they were not released they were worried that their fishing equipment would be damaged. This is in accordance with the results of a research by Sumardi (2014) which stated that $57.7 \%$ of Purse Seine fishermen, $63.2 \%$ of Gill Net fishermen and $54.5 \%$ of Trammel Net fishermen stated that at the time of operation fishing equipment, the protected fish had been caught.

Delpan kriteria yang sudah dijelaskan mengenai alat tangkap diatas yaitu memiliki The eight criteria that have been explained above above fishing equipment are: have high selectivity, do not damage habitat and other organisms, produce good quality fish, do not harm fishermen who operate, catches are safe for consumption, produce little by-catch, low impact towards biodiversity and not catching protected fish; then a fishing gear is said to be sustainable or environmentally friendly if it meets the last requirement which is socially acceptable by the community. The results of the analysis show that the relationship of socioeconomic characteristics to the perception of fishermen in the use of fishing gear is socially acceptable by the community resulting in a correlation relationship that is at very low level and does not have a significant relationship between the two. This is in accordance with Manik's (2013) statement which examines the relationship between fishermen's characteristics and fishermen's attitude towards the Program Pengembangan Perikanan Tangkap (Capture Fisheries Development Program) that the high socio-economic characteristics (age, education level, fishing experience, number of dependents and total income) of fishermen do not cause fishermen to behave positive or negative towards the Program.

\section{CONCLUSION AND RECOMMENDATIONS}

The perception of fishermen in Banda Sakti Subdistrict in Lhokseumawe City that supports the use of sustainable fishing equipment is high, but when viewed from each 
indicator observed, there are 5 indicators with moderate perceptions and 4 indicators with high perceptions.

There is a significant relationship between the variables of the number of dependents on the selectivity of fishing gear and on the variable socialization of fishing equipment that does not harm fishermen.

The income variables and the number of dependents have low correlation with fishermen's perceptions of the selectivity of fishing equipment, while the socialization variables are moderately correlated with fishermen's perceptions of fishing gear that do not harm fishermen. While the other variables are at a very low level of correlation and do not have a significant relationship to the 9 indicators of sustainable fishing equipment.

\section{REFERENCES}

1. Bachtiar, S.A., Setiawan, B., Sunarto. 2003. Persepsi dan Perilaku Nelayan dalam Memanfaatkan Sumber Daya Laut di Pulau Kodingareng Sulawesi Selatan. Pusat Studi Lingkungan Hidup. Universitas Gajah Mada, Yogyakarta.

2. Badan Perencanaan Pembangunan Nasional. 2014. Kajian Strategi Pengelolaan Perikanan Berkelanjutan. Kementerian PPN/Bappenas, Jakarta.

3. Coleman, J. S., 1988. Social Capital in The Creation Of Human Capital. The University Of Chicago Press, American, Vol 94: pp.S95-S120.

4. Doulman, D. 2004. Fisheries Management, Poverty Alleviation and The Implementation of The Code of Conduct For Responsible Fisheries. Springer Science and Business Media Dordrecht .West Africa.

5. Firdaus, M. 2010. Hasil Tangkapan dan Laju Tangkap Unit Perikanan Pukat Tarik, Tugu, dan Kelong. Jurnal Makara. Universitas Indonesia, Depok.

6. Hadi, Sutrisno. 1991. Analisa Butir untuk Instrument. Edisi pertama. Andi Offset. Yogyakarta.

7. Kotler, P. 2000.Prinsip-Prinsip Pemasaran Manajemen. Prenhalindo. Jakarta.

8. Menteri Kelautan dan Perikanan. 2015. Peraturan Menteri Kelautan dan Perikanan Nomor 25/PERMEN-KP/2015 Tentang Rencana Strategis KKP Tahun 2015-2019. Kementerian Kelautan dan Perikanan. Jakarta.

9. Mujiburrahmad, F. 2013. Hubungan Faktor Individu Dan Lingkungan Sosial Dengan Partisipasi Masyarakat Dalam Pengelolaan Sampah Rumah Tangga (Kasus Kampung Sengked, RT03/RW 03 Desa Babakan, Kecamatan Dramaga, Kabupaten Bogor). Tesis. PascaSarjana Institute Pertanian Bogor, Bogor.

10. Mussadun AF, Kusumastanto T, dan Kamal MM. 2011. Analisis Persepsi Nelayan dalam Pengelolaan Sumberdaya Perikanan Berkelanjutan di Taman Nasional Karimunjawa. Jurnal Tata Loka UNDIP. Semarang.

11. Nababan, B. 2017. Persepsi dan Kepatuhan Nelayan TanjungBalai Asahan Sumatera Utara dalam Mendukung Perikanan Tangkap Berkelanjutan. Tesis. Institut Pertanian Bogor, Bogor.

12. Nikijuluw, V.P.H. 2002. Rezim Pengelolaan Sumberdaya Perikanan. PT. Pustaka Cidesindo. Jakarta.

13. Subehi, S., Hery, B.S., Dian, A.N. 2017. Analisis Alat Penangkap Ikan Ramah Lingkungan Berbasis Code of Conduct Responsible Fisheries (CCRF) di TPI Kedung Malang Jepara. Indonesian Journal of Capture Fisheries (IJoCF). Universitas Diponegoro, Semarang.

14. Sugiyono. 2010. Metode Penelitian Pendidikan Pendekatan Kuantitatif, kualitatif, dan R\&D. Alfabeta. Bandung.

15. Suharman. 2005. Psikologi Kognitif. Srikandi. Surabaya.

16. Sumardi, Zainal, M. Ali Sarong, Muhammad Nasir. 2014. Alat Penangkapan Ikan yang Ramah Lingkungan Berbasis Code of Conduct for Responsible Fisheries di Kota Banda Aceh. Agrisep. Universitas Syiah Kuala, Banda Aceh.

17. Sunaryo. 2004. Psikologi untuk Keperawatan. EGC. Jakarta. 
18. Symes, D. 2012. Regionalising The Common Fisheries Policy: Context, content and controversy. Maritime Studies a Springer. University of Hull, UK.

19. Tichenor, J. P., George A., and Clarice N.Olien. 1970. Knowledge Gap Hypothesis Dikutip dalam Teori Komunikasi: Sejarah, Metode, \& Terapan di Dalam Media Massa. Kencana. Jakarta.

20. Tumpak Manik. 2013. Penilaian Nelayan Terhadap Program Pengembangan Perikanan Tangkap Khususnya Pemberian Bantuan Alat Tangkap Ikan (Kasus: Kecamatan Teluk Mengkudu Kabupaten Serdang Bedagai). Universitas Sumatera Utara, Medan.

21. Walgito, Bimo. 2004. Pengantar psikologi Umum. Andi. Jakarta.

22. Wiyono ES. 2009. Persepsi Nelayan terhadap Sumberdaya Perikanan. Jurnal SosialEkonomi Pertanian dan Agribisnis. Institut Pertanian Bogor, Bogor. 